\title{
Dissolution and Passivation of Chalcopyrite during Bioleaching by Acidithiobacillus ferrivorans at Low Temperature
}

\author{
Tangjian Peng ${ }^{1,+}\left(\mathbb{D}\right.$, Lei Chen ${ }^{1,+}$, Jingshu Wang ${ }^{1}$, Jie Miao ${ }^{1}$, Li Shen ${ }^{1,2}$, Runlan Yu ${ }^{1,2}$, \\ Guohua $\mathrm{Gu}^{1,2}$, Guanzhou Qiu ${ }^{1,2}$ and Weimin Zeng 1,2,3,* \\ 1 School of Minerals Processing and Bioengineering, Central South University, Changsha 410083, China; \\ jianshen.yixiao@163.com (T.P.); lu_chang_er_qi@163.com (L.C.); wjs1546389037@outlook.com (J.W.); \\ 201812507@mail.sdu.edu.cn (J.M.); lishen@csu.edu.cn (L.S.); yrl715@sina.com (R.Y.); \\ guguohua@126.com (G.G.); qgz@csu.edu.cn (G.Q.) \\ 2 Key Laboratory of Biometallurgy, Ministry of Education, Changsha 410083, China \\ 3 CSIRO Process Science and Engineering, Clayton, VIC 3168, Australia \\ * Correspondence: zengweimin1024@126.com; Tel.: +86-731-88877472 \\ + Tangjian Peng and Lei Chen contributed equally to this work.
}

Received: 9 April 2019; Accepted: 24 May 2019; Published: 28 May 2019

\begin{abstract}
Our knowledge on the dissolution and passivation mechanisms of chalcopyrite during bioleaching at low temperature has been limited to date. In this study, an Acidithiobacillus ferrivorans strain with high tolerance to heavy metals and UV radiation was used for chalcopyrite bioleaching. At $6^{\circ} \mathrm{C}$, no apparent precipitate was detected on the mineral surface after bioleaching using a scanning electron microscope (SEM). X-ray diffraction (XRD) revealed that the ore residue contained only chalcopyrite and quartz. X-ray photoelectron spectroscopy (XPS) analysis revealed that the content of $\mathrm{S}^{0}$ on the mineral surface remained low and the ratio of $\mathrm{SO}_{4}{ }^{2-}$ decreased from $46.7 \%$ to $20.9 \%$, but the amount of $\mathrm{S}_{\mathrm{n}}{ }^{2-}$ increased from $10.4 \%$ to $21.4 \%$ after bioleaching. Expression of five critical iron- and sulfur-oxidation genes during bioleaching was analyzed using quantitative real-time PCR. The gene rus $A$ had higher expression in the mid-log phase than in the stationary phase but $h d r A$ and cyoC1 showed an opposite trend. All genes had higher expression at $6{ }^{\circ} \mathrm{C}$ than at $28{ }^{\circ} \mathrm{C}$, so as to compensate for the decline in the enzyme activities. The study revealed that polysulfide was the most plausible passivating substance at $6^{\circ} \mathrm{C}$, and the strain can maintain the iron- and sulfur-oxidation activities during low-temperature bioleaching.
\end{abstract}

Keywords: Acidithiobacillus ferrivorans; bioleaching; chalcopyrite; passivation; gene expression

\section{Introduction}

Bioleaching refers to using microorganisms to extract metals from ores and concentrates [1] and it offers an alternative to traditional pyrometallurgical methods for the extraction of valuable metals from sulfide minerals. Extensive studies have been performed on bioleaching on mesophilic, moderate thermophilic and extremely thermophilic conditions [2-8]. However, bioleaching of sulfide minerals at low temperature $\left(<10^{\circ} \mathrm{C}\right)$ was scarcely studied. Several reports revealed the feasibility of bioleaching at low temperature [9-12]. It was found that the dissolution of minerals by microorganisms at $0^{\circ} \mathrm{C}$ can reach $30 \%$ the maximal value at $21^{\circ} \mathrm{C}$ [12]. It has also been shown that ferrous iron can be efficiently oxidized by an Acidithiobacillus ferrivorans strain during bioleaching of sulfide minerals at $4{ }^{\circ} \mathrm{C}$ [13].

Acidithiobacillus ferrivorans is a cold-adapted acidophile which can grow at temperatures as low as $4{ }^{\circ} \mathrm{C}$ and it is able to grow using iron or sulfur as a sole energy source [14]. The iron and sulfur oxidation pathways of $A$. ferrivorans have been discussed previously $[15,16]$. It has been inferred that $A$. 
ferrivorans uses a nearly identical ferrous iron oxidation pathway as the mesophilic A. ferrooxidans for which rus, petI and coxBACD operons encode major proteins involved in iron oxidation and electron transfer [17]. A. ferrivorans has most of the genes encoding proteins involved in sulfur oxidation, such as the $h d r$ cluster encoding heterodisulfide reductase and $\operatorname{dox} D A$ coding for thiosulfate quinone reductase [15].

One of the topics of interest during chalcopyrite bioleaching is that some sulfur rich species would form on the mineral surface and hinder further leaching, which is called passivation. Stott et al. [18] found that a decrease in the dissolution rate of chalcopyrite was consistent with prominent precipitation of jarosite on the mineral surface and proposed that jarosite caused the passivation of chalcopyrite. Yang et al. [19] found that the metal-deficient polysulfide $\left(\mathrm{S}_{\mathrm{n}}{ }^{2-}\right)$ was slowly leached and proposed that polysulfide led to the passivation of chalcopyrite. A similar viewpoint was also provided by Ghahremaninezhad et al. [20]. To date, only one relevant study was performed on the passivation of chalcopyrite at low temperature. It was observed that elemental sulfur accumulated until metal dissolution stopped during chalcopyrite bioleaching at $6{ }^{\circ} \mathrm{C}$ and $\mathrm{S}^{0}$ was considered as a passivating substance [16]. Despite this, the dissolution and passivation of chalcopyrite at low temperatures need to be further elucidated.

The present work described the bioleaching of chalcopyrite by an Acidithiobacillus ferrivorans strain YL15. The strain was isolated from acid mine drainage in Tibet, China [21]. The physiological features of the strain were characterized. The passivation mechanism of chalcopyrite during bioleaching at low temperature and the expression of the critical iron- and sulfur-oxidation genes during bioleaching were analyzed. The present work would provide further insights into the dissolution and passivation of chalcopyrite and the metabolism of a cold-adapted acidophile during bioleaching.

\section{Materials and Methods}

\subsection{Microorganisms}

A. ferrivorans strain YL15 was isolated from acid mine drainage of Yulong copper mine using the FeTSB solid medium [22]. The growth temperature and $\mathrm{pH}$ range and autotrophic or organotrophic growth were tested as previously described [14]. Heavy metal resistance of strain YL15 was tested as described in previous work [23]. To test the UV radiation (UVR) tolerance, stain YL15 was cultured in ferrous iron liquid medium to the exponential phase. The cells were harvested by centrifugation, washed and resuspended with sterilized acidified water ( $\mathrm{pH}$ 2.0). Aliquots were spread on FeTSB solid medium and the plates were exposed to UV (254 nm) at a distance of $30 \mathrm{~cm}$ for 2, 4, 6, 8, 10 and 12 min with the lids open. After that, the irradiated plates were cultured at $28^{\circ} \mathrm{C}$ for 3 weeks. In order to avoid photorepair, the experiment was performed in a dark room and the plates were wrapped by tin foil paper. A. ferrooxidans ATCC $23270^{\mathrm{T}}$ was tested as a control (except the cultivation temperature was $30^{\circ} \mathrm{C}$ ).

\subsection{Mineral}

Chalcopyrite was obtained from Guangzhou in Guangdong province, China. X-ray diffraction (XRD) analysis showed that the chalcopyrite sample was of high purity (consisted of $97.83 \%$ chalcopyrite and $2.17 \%$ quartz) and the main chemical elements were $\mathrm{Cu}(33.1 \%), \mathrm{Fe}(28.7 \%), \mathrm{S}(35.4 \%), \mathrm{Si}(1.3 \%)$ and O (1.5\%). Sample was ground and sieved, with fractional sizes $<75 \mu \mathrm{m}$, and sterilized by UV irradiation for $24 \mathrm{~h}$ in an aseptic room.

\subsection{Bioleaching Experiments}

Bioleaching experiments were conducted in $500 \mathrm{~mL}$ shake flasks. Chalcopyrite ( $3 \%$ pulp density) and $250 \mathrm{~mL}$ iron-free 9K medium [24] were added into the flasks. Iron-grown cells at mid-logarithmic phase were centrifuged at $8000 \times g$ for $10 \mathrm{~min}$ to obtain the pellets. Then, the cell pellets were washed twice using sterilized acidified water $(\mathrm{pH} 2.0)$ and resuspended into the medium and adjusted to obtain an initial density of $2 \times 10^{7}$ cells/mL. Chalcopyrite was bioleached at $6{ }^{\circ} \mathrm{C}$ operated at $160 \mathrm{r} / \mathrm{min}$ 
(designated as A-6). For comparison, bioleaching at $28^{\circ} \mathrm{C}$ was also performed (A-28). The experiments were carried out in triplicate. Sterile controls were carried out in duplicate (designated as B-6 and B-28, respectively). Deionized water was added to compensate for the water loss by evaporation. Conditions for all the experiments were shown in Table S1.

Samples were collected at regular intervals to measure the $\mathrm{pH}$, oxidation reduction potential (ORP), ion concentrations and cell density. The concentration of total soluble iron (tFe) in solution was determined by inductively coupled plasma optical emission spectrophotometer (Perkin Elmer, Norwalk, CT, USA). Ferrous iron and copper concentrations were assayed by phenanthroline and bisoxaldihydrazone spectrophotometric method $[25,26]$, respectively. The $\mathrm{pH}$ value was measured with a pHS-3E acid meter (LEICI, Shanghai, China) and the ORP (vs. Ag/AgCl) value was measured with a platinum electrode as a reference. Cells were counted with a blood cell counting chamber under a CX31 optical microscope (Olympus, Tokyo, Japan).

\subsection{Characterization of Ore Residues}

Ore residues were withdrawn from the bioleaching solution, filtered, washed with pre-cooling $\mathrm{ddH}_{2} \mathrm{O}\left(\mathrm{pH} 2.0,4^{\circ} \mathrm{C}\right)$ thrice and dried in a DZF-60508 vacuum drying chamber (YIHENG, Shanghai, China) at room temperature for $24 \mathrm{~h}$. Corrosion of chalcopyrite was visualized by a Quanta 200 environmental scanning electron microscope (ESEM) (FEI, Hillsboro, OR, USA). Secondary electron imaging was performed at a beam energy of $15 \mathrm{kV}$ and a probe current of 140-145 pA. Components of ore residues were analyzed by XRD (Panalytical, X'pert Pro, Almelo, The Netherlands) with Cu K $\alpha$ radiation $(40 \mathrm{kV}, 35 \mathrm{~mA})$ conducted from $5^{\circ}$ to $80^{\circ}(2 \theta)$ at a goniometer speed of $4^{\circ} / \mathrm{min}$.

XPS analysis was performed using ESCALAB 250XI (Thermo Scientific, Waltham, MA, USA). Spectra were recorded at a constant pass energy of $20 \mathrm{eV}$ and $0.1 \mathrm{eV} /$ step using Al Ka X-ray source. Peaks of S 2p were fitted using Avantage (Version 5.52, Thermo Scientific, Waltham, MA, USA). The Savitsky-Golay model and Smart method were used for line smoothing and obtaining the background of spectra, respectively. Binding energies were referred to the C 1s level at $284.8 \mathrm{eV}$. The binding energy (BE) and full width at half maximum (FWHM) of each sulfur species were referred to in previous documents [27]. Due to the spin-orbit splitting, the $S 2 p$ peaks occurred as doublets with $S 2 p_{3 / 2}$ and $S 2 p_{1 / 2}$ and the peak area ratio is $2: 1$ and $1.2 \mathrm{eV}$ splitting for $S 2 p_{3 / 2}$ and $S 2 p_{1 / 2}$. The ratio of each sulfur species was automatically calculated by Avantage 5.52 based on the area of each peak.

\subsection{Quantification of Gene Expression during Bioleaching}

Bioleaching solution was rapidly cooled as previously described [28] and centrifuged at $8000 \times g$ for $5 \mathrm{~min}$ at $4{ }^{\circ} \mathrm{C}$ to collect the cells. Then the total RNA was extracted using Total RNApure kit (Zoman, Beijing, China) as per the manufacturer's instructions. The quality of total extracted RNA was confirmed by $1 \%$ agarose gel electrophoresis and quantified using the NanoDrop ND-1000 Spectrophotometer. Trace genomic DNA was digested using gDNA Wiper kit (Zoman, Beijing, China). In order to confirm that trace genomic DNA has been removed, the genomic DNA of strain YL15 was extracted as described in another article [29], and partial sequence of the 16S rRNA gene was amplified using primers 515F and 806R using the genomic DNA and the product of gDNA Wiper kit as templates, respectively. Positive and negative results were obtained when using the former and the later as templates, respectively. After that, the digestion product was retro-transcribed into cDNA with Reverse Transcriptase (Zoman, Beijing, China) and random primers. The cDNA was diluted by 10 -fold and stored at $-80^{\circ} \mathrm{C}$ until use.

Expression of the critical iron- and sulfur-oxidation genes was determined during bioleaching by quantitative real-time PCR. Sequences of the selected genes (Table S2) were retrieved from NCBI Genbank and the specific primers (Table S2) were designed using Primer Premier 5.0 and Oligo 7.0. Conventional PCR was performed, and the PCR products were purified for sequencing to verify the accuracy of the primers and the sizes of PCR products. The PCR program was conducted at $95^{\circ} \mathrm{C}$ for $5 \mathrm{~min}$, followed by 30 cycles of denaturation at $94^{\circ} \mathrm{C}$ for $1 \mathrm{~min}$, annealing at proper temperatures for $1 \mathrm{~min}$ and elongation at $72{ }^{\circ} \mathrm{C}$ for $15 \mathrm{~s}$ and a final elongation at $72{ }^{\circ} \mathrm{C}$ for $10 \mathrm{~min}$. 
Quantitative real-time PCR was performed using a MyiQ ${ }^{\mathrm{TM}}$ real-time PCR detection system (Bio-Rad Laboratories Inc., Hercules, CA, USA) in a $20 \mu \mathrm{L}$ reaction mixture consisting of AceQ qPCR SYBR Green Master Mix $(10 \mu \mathrm{L})$, primer (each $2.0 \mu \mathrm{M})$, cDNA template $(2.0 \mu \mathrm{L})$ and ddH $\mathrm{H}_{2} \mathrm{O}(7.2 \mu \mathrm{L})$. The real-time PCR program was one cycle of $95^{\circ} \mathrm{C}$ for $5 \mathrm{~min}$, and then 40 cycles of $95{ }^{\circ} \mathrm{C}$ for $30 \mathrm{~s}$, $55{ }^{\circ} \mathrm{C}$ for $30 \mathrm{~s}$, and $72{ }^{\circ} \mathrm{C}$ for $30 \mathrm{~s}$. The melting curve for each amplicon was measured by raising the temperature from 55 to $95^{\circ} \mathrm{C}$ at $0.5^{\circ} \mathrm{C} / \mathrm{s}$ after the completion of each run while monitoring fluorescence. The specificity of the PCR primers was checked by examining the symmetry of melting curve and the lack of non-specific peaks [30]. The glyceraldehyde-3-phosphate dehydrogenase gene (gapdh) was used as a reference [21]. All tests were conducted in triplicate. Statistical analysis was performed using the Student's t-test in R (version 3.3.3, Statistics Department of the University of Auckland, Auckland, New Zealand).

\section{Results and Discussion}

\subsection{Characterization of Strain YL15}

Strain YL15 is similar to other described strains of $A$. ferrivorans in the growth at low temperature, utilization of inorganic and organic substances and tolerance to $\mathrm{pH}$ (Table S3). Strain YL15 can tolerate high concentrations of heavy metals (Table 1). The strain was much more resistant to heavy metals than the previously described $A$. ferrivorans strains, which were reported to be inhibited by $<50 \mathrm{mM} \mathrm{Cu}$ (II) (3.2 g/L) or $<100 \mathrm{mM}$ Fe(III) (5.6 g/L) [14]. Strain YL15 can tolerate a high dose of UVR. The upper limit exposure time (at which growth was observed on FeTSB plates) to UV for strain YL15 was 8 min, higher than the A. ferrooxidans type strain ATCC 23,270 (4 min).

Table 1. Metal resistance of A. ferrivorans YL15. A. ferrooxidans ATCC $23270^{\mathrm{T}}$ was used as a reference. Metals were added as sulfate salts. The concentration of metals was shown in $\mathrm{g} / \mathrm{L}$. Values were shown as the highest concentrations at which cell growth were observed and the numbers in parentheses were the minimum inhibitory concentrations (MICs).

\begin{tabular}{cccccccc}
\hline Strain & Fe(II) & Fe(III) & Cu(II) & Zn(II) & Co(II) & Ni(II) & Mn(II) \\
\hline YL15 & $22.3(27.9)$ & $16.8(22.3)$ & $25.4(31.8)$ & $52.3(58.9)$ & $29.5(35.4)$ & $11.7(17.6)$ & $22.0(27.5)$ \\
ATCC 23270 & $22.3(27.9)$ & $16.8(22.3)$ & $19.06(25.4)$ & $52.3(58.9)$ & $23.6(29.5)$ & $5.9(11.7)$ & $16.5(22.0)$ \\
\hline
\end{tabular}

\subsection{Bioleaching of Chalcopyrite by Strain YL15}

During bioleaching of chalcopyrite, cell density began to increase after a lag phase at $6{ }^{\circ} \mathrm{C}$ and $28{ }^{\circ} \mathrm{C}$ (24 and 12 days, respectively) (Figure 1a). The pH decreased to 2.0 and 1.8 at $6{ }^{\circ} \mathrm{C}$ and $28{ }^{\circ} \mathrm{C}$, respectively (Figure $1 \mathrm{~b}$ ). At $6{ }^{\circ} \mathrm{C}$ and $28^{\circ} \mathrm{C}$, the cells entered the stationary phase after days 36 and 28 , respectively. The stationary phase was long. This was because chalcopyrite is leached via the polysulfide pathway, during which time elemental sulfur is formed [31] and cells can grow using elemental sulfur as a main energy source.

The variation of copper during bioleaching was shown in Figure 2. The slight increase in copper concentration in the early phase resulted from the proton attack on chalcopyrite, which was consistent with the rise in $\mathrm{pH}$ (Figure $1 \mathrm{~b}$ ). Thereafter, copper concentration increased rapidly, and reached the highest level at $6{ }^{\circ} \mathrm{C}(1.02 \mathrm{~g} / \mathrm{L})$ on day 52 and $28{ }^{\circ} \mathrm{C}$ on day $40(1.53 \mathrm{~g} / \mathrm{L})$, respectively. The highest copper concentration rate at $6^{\circ} \mathrm{C}(10.3 \%)$ and $28^{\circ} \mathrm{C}(15.4 \%)$ were much higher than those of the abiotic controls $\left(2.9 \%\right.$ at $6{ }^{\circ} \mathrm{C}$ and $3.2 \%$ at $\left.28{ }^{\circ} \mathrm{C}\right)$, indicating that strain YL15 significantly accelerated the leaching of chalcopyrite. 

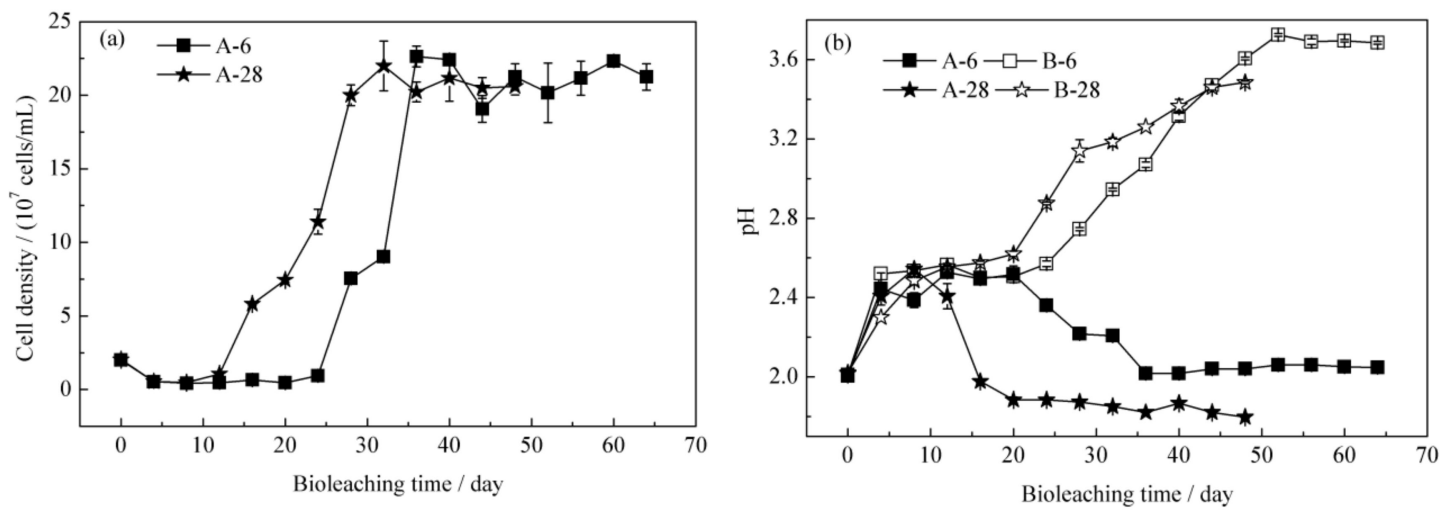

Figure 1. The dynamics of cell density (a) and $\mathrm{pH}(\mathbf{b})$ at $6{ }^{\circ} \mathrm{C}$ and $28{ }^{\circ} \mathrm{C}$ during bioleaching of chalcopyrite. A-6, chalcopyrite bioleaching by strain YL15 at $6{ }^{\circ} \mathrm{C}$; A-28, chalcopyrite bioleaching by strain YL15 at $28{ }^{\circ} \mathrm{C}$; B-6, abiotic control at $6{ }^{\circ} \mathrm{C}$; B-28, abiotic control at $28{ }^{\circ} \mathrm{C}$.

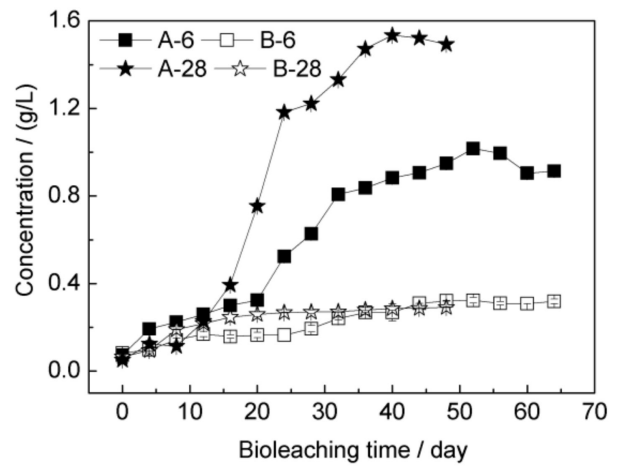

Figure 2. The variation of copper concentration at $6{ }^{\circ} \mathrm{C}$ and $28{ }^{\circ} \mathrm{C}$ during bioleaching of chalcopyrite.

At $6{ }^{\circ} \mathrm{C}$, the leaching rate was fast on days 20-32, meanwhile, the ORP value increased rapidly from about $\sim 330 \mathrm{mV}$ to $\sim 580 \mathrm{mV}$ (Figure 3a). The sharp increase of ORP was due to the consumption of ferrous iron and the increase of ferric iron concentration (Figure S1 and Figure 3b). Comparatively, this process was shorter at $6{ }^{\circ} \mathrm{C}$ than at $28^{\circ} \mathrm{C}$. At $28^{\circ} \mathrm{C}$, dissolution of chalcopyrite was rapid on days 8-24, during which the ORP increased from $340-480 \mathrm{mV}$. This difference was mainly due to that at $6{ }^{\circ} \mathrm{C}$, ferric iron oxidized chalcopyrite and regenerated ferrous iron slower than at $28^{\circ} \mathrm{C}$ and that ferric iron scarcely formed precipitate at low temperature (see results of SEM and XRD).
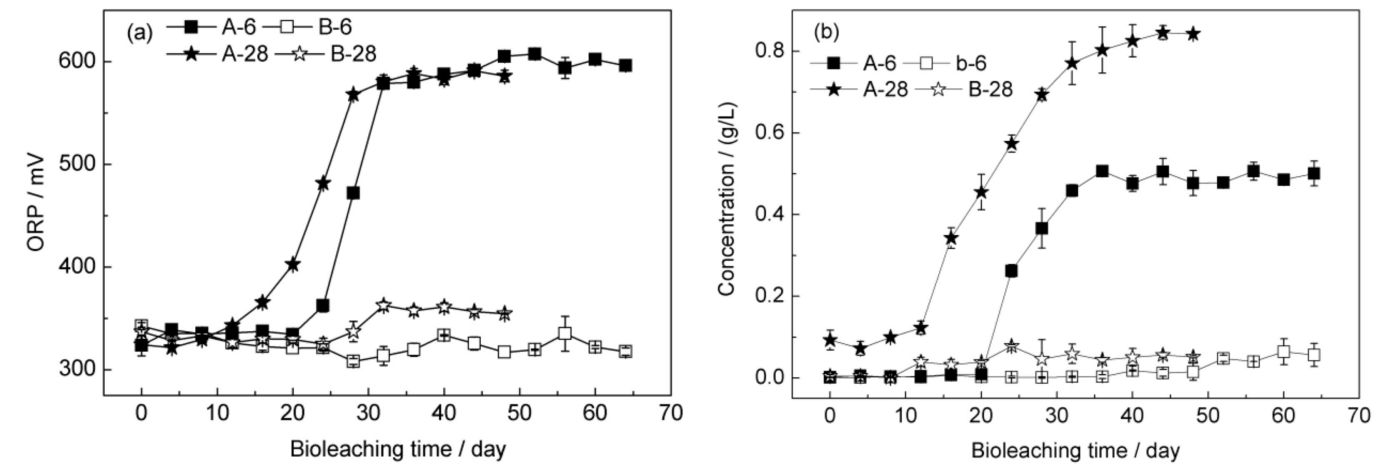

Figure 3. The dynamics of ORP (a) and ferric iron concentration (b) at $6{ }^{\circ} \mathrm{C}$ and $28{ }^{\circ} \mathrm{C}$ during chalcopyrite bioleaching. 


\subsection{Passivation of the Mineral Surface at $6{ }^{\circ} \mathrm{C}$}

At high ORP value, dissolution of chalcopyrite slowed down and finally stagnated, mainly due to the passivation of the mineral surface. Previous studies have shown that elemental sulfur $\left(\mathrm{S}^{0}\right)$, polysulfide $\left(\mathrm{S}_{\mathrm{n}}{ }^{2-}\right.$ ) or jarosite (represented by $\mathrm{SO}_{4}{ }^{2-}$ ) could be the main component of a passivation layer $[19,32,33]$. SEM and XRD have been used to detect the formation of jarosite and confirmed jarosite passivation during bioleaching [18]. To find out whether jarosite caused the passivation of the mineral surface at $6^{\circ} \mathrm{C}$, the surface of chalcopyrite before and after bioleaching was tested first using SEM. It was shown no apparent precipitate was observed on the mineral surface at $6{ }^{\circ} \mathrm{C}$ compared to a large amount of precipitate formed at $28^{\circ} \mathrm{C}$ (Figure 4). The ore residues after bioleaching were analyzed by XRD. The result showed that no jarosite was detected on the mineral surface at $6{ }^{\circ} \mathrm{C}$ compared to $20.3 \%$ jarosite of the total mass at $28^{\circ} \mathrm{C}$ (Figure 5). Therefore, data of SEM and XRD could not confirm the jarosite passivation at $6{ }^{\circ} \mathrm{C}$.

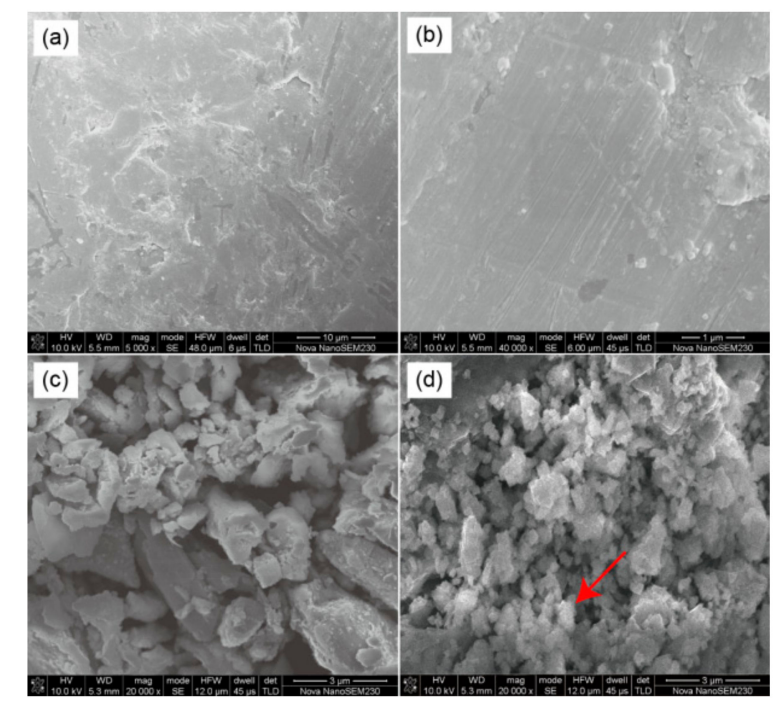

Figure 4. SEM images of the surface of chalcopyrite before and after bioleaching: (a) before bioleaching; (b) abiotic control at $6{ }^{\circ} \mathrm{C}$; (c) bioleaching at $6{ }^{\circ} \mathrm{C}$; (d) bioleaching at $28^{\circ} \mathrm{C}$. Results of abiotic control at $6{ }^{\circ} \mathrm{C}$ and $28^{\circ} \mathrm{C}$ were similar, therefore only that at $6^{\circ} \mathrm{C}$ was shown. The red arrow indicates the formed precipitate.
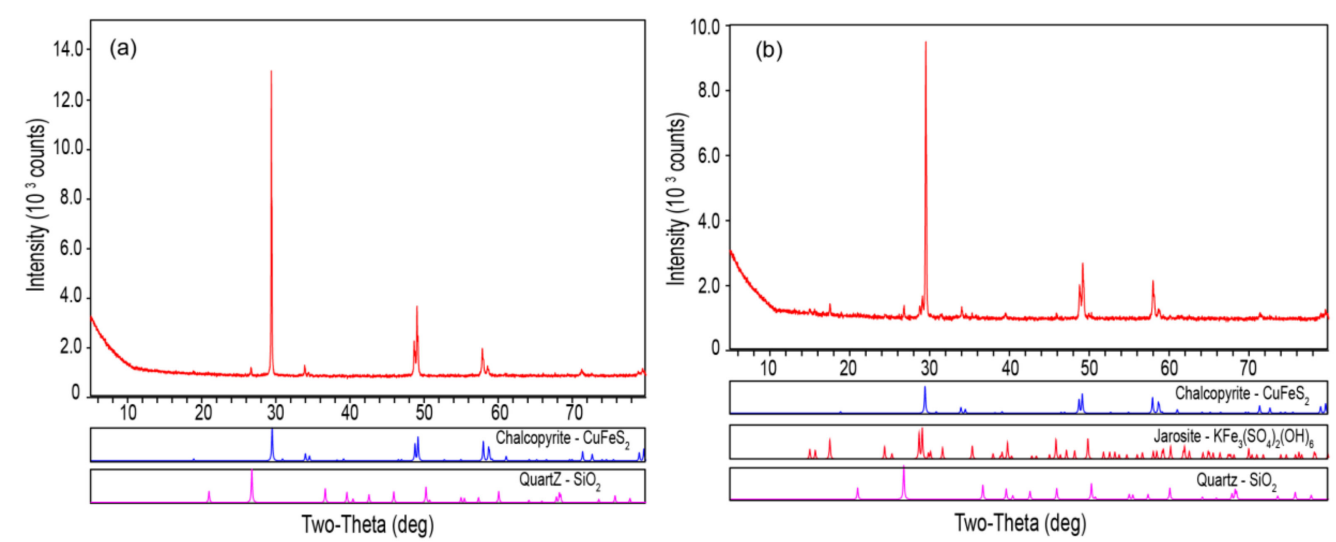

Figure 5. Compositions of ore residues of chalcopyrite analyzed by XRD after bioleaching at $6{ }^{\circ} \mathrm{C}(\mathrm{a})$ and $28^{\circ} \mathrm{C}(\mathbf{b})$.

To further unravel the passivation species at $6{ }^{\circ} \mathrm{C}$, the sulfur species on the surface of chalcopyrite before and after bioleaching was analyzed using XPS. The S $2 \mathrm{p}$ peaks of chalcopyrite sample of before leaching and after bioleaching for 26 days were fitted. Elemental sulfur $\left(\mathrm{S}^{0}\right)$, monosulfide $\left(\mathrm{S}^{2-}\right)$, 
disulfide $\left(\mathrm{S}_{2}{ }^{2-}\right)$, polysulfide $\left(\mathrm{S}_{\mathrm{n}}{ }^{2-}\right)$ and sulfate $\left(\mathrm{SO}_{4}{ }^{2-}\right)$ were detected (Figure 6) and the BE and FWHM of each species are shown in Table 2.
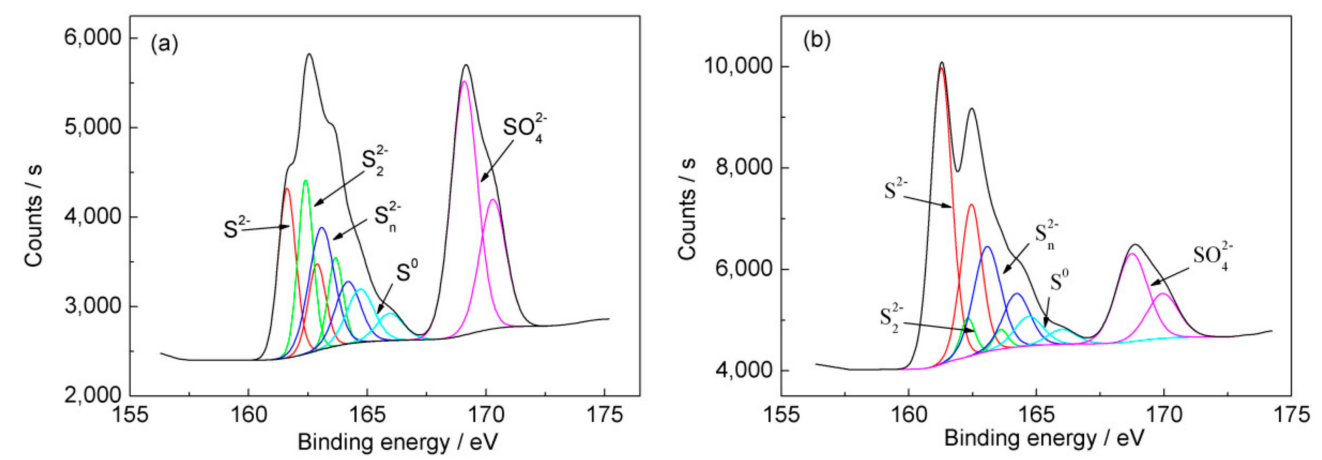

Figure 6. The S $2 \mathrm{p}$ spectra of chalcopyrite surface before (a) and after bioleaching (b) at $6{ }^{\circ} \mathrm{C}$.

Table 2. BE and FWHM of each sulfur species detected by XPS in in the original ore sample and ore residue on day 26.

\begin{tabular}{ccccccccccc}
\hline \multirow{2}{*}{ Sample } & \multicolumn{2}{c}{$\mathbf{S}^{\mathbf{2}}$} & \multicolumn{2}{c}{$\mathbf{S}_{\mathbf{2}}{ }^{2-}$} & \multicolumn{2}{c}{$\mathbf{S}_{\mathbf{n}}{ }^{2-}$} & \multicolumn{2}{c}{$\mathbf{S}^{\mathbf{2}}$} & \multicolumn{2}{c}{$\mathbf{S O}_{4}{ }^{2-}$} \\
\cline { 2 - 12 } & BE & FWHM & BE & FWHM & BE & FWHM & BE & FWHM & BE & FWHM \\
\hline Before bioleaching & 161.6 & 0.87 & 162.4 & 0.75 & 163.1 & 1.25 & 164.7 & 1.35 & 169.0 & 1.30 \\
Ore residue & 161.3 & 0.98 & 162.3 & 0.67 & 163.1 & 1.25 & 164.7 & 1.35 & 168.8 & 1.46 \\
\hline
\end{tabular}

The ratio of each species was calculated based on the area of its peak and shown in Table 3 . Among the detected sulfur species, elemental sulfur $\left(S^{0}\right)$, polysulfide $\left(S_{n}{ }^{2-}\right)$ or jarosite (represented by $\mathrm{SO}_{4}{ }^{2-}$ ) have been reported to be the main component of a passivation layer [19,32,33]. In the present study, the content of $S^{0}$ on the mineral surface was low in both the initial ore sample and the ore residue on day 26. It was assumed that the produced $S^{0}$ can be eliminated by sulfur-oxidizing microorganisms at low temperature. This was confirmed by the results of expression of sulfur-oxidation genes (see below). Therefore, elemental sulfur was not the main component of passivation layer during bioleaching at $6{ }^{\circ} \mathrm{C}$. The content of $\mathrm{SO}_{4}{ }^{2-}$ (jarosite) on the mineral surface was $46.7 \%$ in the initial sample, but decreased to $20.9 \%$ after bioleaching. This indicated that jarosite can be removed or eliminated at $6{ }^{\circ} \mathrm{C}$ and that it did not play a major role in the passivation of chalcopyrite. On the other hand, the ratio of polysulfide on the mineral surface was low in the initial ore sample, but increased to $21.4 \%$ after bioleaching. Therefore, polysulfide was the most plausible passivation substance during bioleaching at $6^{\circ} \mathrm{C}$.

Table 3. Ratios of sulfur species in the original ore sample and ore residue on day 26.

\begin{tabular}{cccccc}
\hline Sample & $\mathbf{S}^{\mathbf{0}}$ & $\mathbf{S}_{\mathbf{n}}{ }^{2-}$ & $\mathbf{S O}_{4}{ }^{2-}$ & $\mathbf{S}^{2-}$ & $\mathbf{S}_{\mathbf{2}}{ }^{2-}$ \\
\hline Before bioleaching & 8.6 & 10.4 & 46.7 & 18.7 & 15.6 \\
Ore residue & 6.4 & 21.4 & 20.9 & 47.1 & 4.2 \\
\hline
\end{tabular}

\subsection{Expression of Critical Iron- and Sulfur-Oxidation Associated Genes during Bioleaching}

Expression of iron- and sulfur-oxidation related genes was monitored at different time points during bioleaching using quantitative real-time PCR. For iron-oxidation related genes, rus $A$ and $c y c A 1$ were selected, and for sulfur-oxidation genes, $h d r A, c y o C 1$ and $d o x D A$ were selected (Table S2). Samples were withdrawn during the mid-log (day 32 at $6{ }^{\circ} \mathrm{C}$ and day 25 at $28{ }^{\circ} \mathrm{C}$ ) and stationary phases (days 45 and 60 at $6{ }^{\circ} \mathrm{C}$ and days 35, 45 at $28^{\circ} \mathrm{C}$ ). Expression of rus $A$ was higher than that of other genes, especially during the mid-log phase, but after that a decline in the expression level was observed. Expression of $c y c A 1$ was steady at $6{ }^{\circ} \mathrm{C}$ but higher during the mid-log than stationary phase 
at $28^{\circ} \mathrm{C}$ (Figure 7). The result revealed the importance of rus $A$ as a central hub in the iron-oxidation pathway and that iron oxidation was more prominent in the mid-log phase, which was consistent with the rapid rise in the concentration of ferric iron. Ferric iron is the main oxidant that attack chalcopyrite, therefore, the copper release was rapid in this phase. On the other hand, expression of $h d r A$ and cyoC1 did not decreased after the mid-log phase, instead, it increased in the stationary phase (Figure 7), which was in accordance with cells mainly using sulfur as an energy source during this phase, and $\mathrm{pH}$ kept decreasing after the $\log$ phase (Figure $1 b$ ). The gene $\operatorname{dox} D A$ encodes the thiosulfate quinone oxidoreductase, which catalyzes thiosulfate to tetrathionate. The expression of $\operatorname{doxDA}$ was low due chalcopyrite being oxidized via the polysulfide pathway, during which thiosulfate in not the main intermediate product [31].
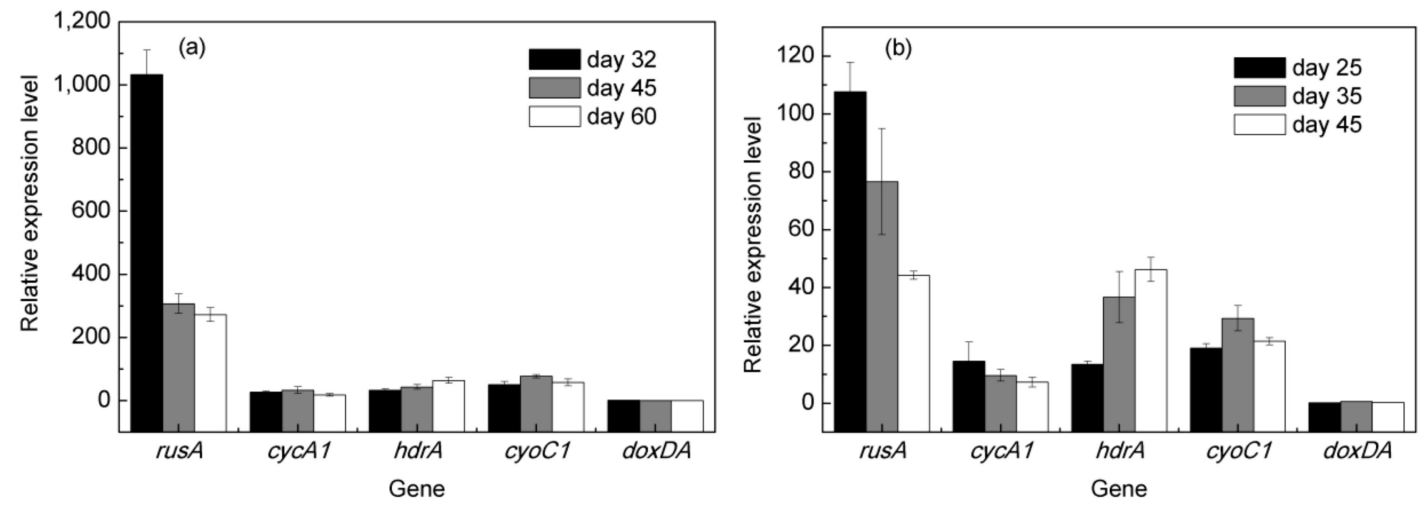

Figure 7. Expression of selected iron- and sulfur-oxidation associated genes during bioleaching of chalcopyrite at $6{ }^{\circ} \mathrm{C}(\mathbf{a})$ and $28{ }^{\circ} \mathrm{C}(\mathbf{b})$. The relative expression level was the absolute cDNA copy number of functional gene relative to gapdh. Note that the scales of (a) and (b) were different.

In order to reveal the difference in iron- and sulfur-oxidation activities during bioleaching at low and mesophilic temperatures, gene expression in mid-log phase at $6^{\circ} \mathrm{C}$ and $28{ }^{\circ} \mathrm{C}$ was compared. All of the five genes had higher expression at $6^{\circ} \mathrm{C}$ than at $28^{\circ} \mathrm{C}$ (Table S4). In particular, expression of rus $A$ was up-regulated by 9.59 folds at $6^{\circ} \mathrm{C}(p<0.05)$. This indicated that the strain can increase its gene expression level to compensate for the decline in the enzyme activities at low temperature, so as to maintain the iron and sulfur-oxidation activities.

\section{Conclusions}

An A. ferrivorans strain YL15 was characterized and used in chalcopyrite bioleaching. The strain can tolerate elevated concentration of heavy metals and a high dose of UVR. During bioleaching at $6{ }^{\circ} \mathrm{C}$, polysulfide rather than jarosite would be mainly responsible for passivation of the mineral surface. Expression of iron- and sulfur-oxidation genes indicated a switch from iron to sulfur oxidation from log to stationary phase and that copper extraction was rapid when iron oxidation activity was high. The up-regulation of the genes suggested the maintenance of iron- and sulfur-oxidation activities in a low-temperature bioleaching system.

Supplementary Materials: The following are available online at http://www.mdpi.com/2075-163X/9/6/332/s1, Table S1: Conditions for the bioleaching experiments, Table S2: Selected functional genes and primers, Table S3: Taxonomic traits of YL15 and the reported isolates of the species Acidithiobacillus ferrivorans, Table S4: A comparison of the relative gene expression at $6{ }^{\circ} \mathrm{C}$ and $28{ }^{\circ} \mathrm{C}$ in the mid-log phase during bioleaching of chalcopyrite, Figure S1: The dynamics of ferrous iron concentration at $6{ }^{\circ} \mathrm{C}$ and $28{ }^{\circ} \mathrm{C}$ during bioleaching of chalcopyrite. References [14,34-36] are cited in the supplementary materials.

Author Contributions: Conceptualization, G.G. and W.Z.; Formal analysis, T.P. and L.C.; Funding acquisition, L.S., R.Y., G.G., G.Q. and W.Z.; Investigation, L.C., J.W. and J.M.; Methodology, T.P.; Project administration, G.G., G.Q. and W.Z.; Software, T.P. and L.C.; Supervision, L.S. and R.Y.; Validation, G.G., G.Q. and W.Z.; Visualization, T.P., J.W. and J.M.; Writing—original draft, T.P. and L.C.; Writing-review \& editing, G.G., G.Q. and W.Z. 
Funding: This work was funded by the National Natural Science Foundation of China, grant numbers 31470230, 51320105006, 51374249 and 51604308, the Youth Talent Foundation of Hunan Province of China, grant number 2017RS3003, Natural Science Foundation of Hunan Province of China, grant number 2018JJ2486 and postdoctoral research funding plan in Hunan province (grant number 207159) and Central South University (grant number 140050014).

Conflicts of Interest: The authors declare no conflict of interest.

\section{References}

1. Johnson, D.B.; Grail, B.M.; Hallberg, K.B. A new direction for biomining: Extraction of metals by reductive dissolution of oxidized ores. Minerals 2013, 3, 49-58. [CrossRef]

2. Li, Q.; Yang, B.; Zhu, J.; Jiang, H.; Li, J.; Zhang, R.; Sand, W. Comparative analysis of attachment to chalcopyrite of three mesophilic iron and/or sulfur-oxidizing acidophiles. Minerals 2018, 8, 406. [CrossRef]

3. Panda, S.; Parhi, P.K.; Nayak, B.D.; Pradhan, N.; Mohapatra, U.B.; Sukla, L.B. Two step meso-acidophilic bioleaching of chalcopyrite containing ball mill spillage and removal of the surface passivation layer. Bioresour. Technol. 2013, 130, 332-338. [CrossRef] [PubMed]

4. Acosta, M.; Galleguillos, P.; Ghorbani, Y.; Tapia, P.; Contador, Y.; Velásquez, A.; Espoz, C.; Pinilla, C.; Demergasso, C. Variation in microbial community from predominantly mesophilic to thermotolerant and moderately thermophilic species in an industrial copper heap bioleaching operation. Hydrometallurgy 2014, 150, 281-289. [CrossRef]

5. Behrad Vakylabad, A. A comparison of bioleaching ability of mesophilic and moderately thermophilic culture on copper bioleaching from flotation concentrate and smelter dust. Int. J. Miner. Process. 2011, 101, 94-99. [CrossRef]

6. Vera, M.; Schippers, A.; Sand, W. Progress in bioleaching: fundamentals and mechanisms of bacterial metal sulfide oxidation-part A. Appl. Microbiol. Biotechnol. 2013, 97, 7529-7541. [CrossRef] [PubMed]

7. Peng, T.; Zhou, D.; Liu, Y.; Yu, R.; Qiu, G.; Zeng, W. Effects of $\mathrm{pH}$ value on the expression of key iron/sulfur oxidation genes during bioleaching of chalcopyrite on thermophilic condition. Ann. Microbiol. 2019, 69, 627-635. [CrossRef]

8. Ai, C.; McCarthy, S.; Liang, Y.; Rudrappa, D.; Qiu, G.; Blum, P. Evolution of copper arsenate resistance for enhanced enargite bioleaching using the extreme thermoacidophile Metallosphaera sedula. J. Ind. Microbiol. Biotechnol. 2017, 44, 1613-1625. [CrossRef] [PubMed]

9. Elberling, B.; Schippers, A.; Sand, W. Bacterial and chemical oxidation of pyritic mine tailings at low temperatures. J. Contam. Hydrol. 2000, 41, 225-238. [CrossRef]

10. Escobar, B.; Buccicardi, S.; Morales, G.; Wiertz, J. Biooxidation of ferrous iron and sulphide at low temperatures: Implications on acid mine drainage and bioleaching of sulphide minerals. Hydrometallurgy 2010, 104, 454-458. [CrossRef]

11. Halinen, A.K.; Rahunen, N.; Kaksonen, A.H.; Puhakka, J.A. Heap bioleaching of a complex sulfide ore: Part II. Effect of temperature on base metal extraction and bacterial compositions. Hydrometallurgy 2009, 98, 101-107. [CrossRef]

12. Langdahl, B.R.; Ingvorsen, K. Temperature characteristics of bacterial iron solubilisation and ${ }^{14} \mathrm{C}$ assimilation in naturally exposed sulfide ore material at Citronen Fjord, North Greenland ( $\left.83^{\circ} \mathrm{N}\right)$. Fems Microbiol. Ecol. 1997, 23, 275-283. [CrossRef]

13. Dopson, M.; Halinen, A.K.; Rahunen, N.; Ozkaya, B.; Sahinkaya, E.; Kaksonen, A.H.; Lindstrom, E.B.; Puhakka, J.A. Mineral and iron oxidation at low temperatures by pure and mixed cultures of acidophilic microorganisms. Biotechnol. Bioeng. 2007, 97, 1205-1215. [CrossRef]

14. Hallberg, K.B.; Gonzalez-Toril, E.; Johnson, D.B. Acidithiobacillus ferrivorans, sp. nov.; facultatively anaerobic, psychrotolerant iron-, and sulfur-oxidizing acidophiles isolated from metal mine-impacted environments. Extremophiles 2010, 14, 9-19. [CrossRef] [PubMed]

15. Talla, E.; Hedrich, S.; Mangenot, S.; Ji, B.; Johnson, D.B.; Barbe, V.; Bonnefoy, V. Insights into the pathways of iron- and sulfur-oxidation, and biofilm formation from the chemolithotrophic acidophile Acidithiobacillus ferrivorans CF27. Res. Microbiol. 2014, 165, 753-760. [CrossRef] [PubMed]

16. Liljeqvist, M.; Rzhepishevska, O.I.; Dopson, M. Gene identification and substrate regulation provide insights into sulfur accumulation during bioleaching with the psychrotolerant acidophile Acidithiobacillus ferrivorans. Appl. Env. Microbol. 2013, 79, 951-957. [CrossRef] [PubMed] 
17. Quatrini, R.; Appia-Ayme, C.; Denis, Y.; Jedlicki, E.; Holmes, D.S.; Bonnefoy, V. Extending the models for iron and sulfur oxidation in the extreme acidophile Acidithiobacillus ferrooxidans. BMC Genom. 2009, 10, $394-412$. [CrossRef]

18. Stott, M.; Watling, H.; Franzmann, P.; Sutton, D. The role of iron-hydroxy precipitates in the passivation of chalcopyrite during bioleaching. Min. Eng. 2000, 13, 1117-1127. [CrossRef]

19. Yang, Y.; Liu, W.; Chen, M. A copper and iron K-edge XANES study on chalcopyrite leached by mesophiles and moderate thermophiles. Min. Eng. 2013, 48, 31-35. [CrossRef]

20. Ghahremaninezhad, A.; Dixon, D.G.; Asselin, E. Electrochemical and XPS analysis of chalcopyrite $\left(\mathrm{CuFeS}_{2}\right)$ dissolution in sulfuric acid solution. Electrochim. Acta 2013, 87, 97-112. [CrossRef]

21. Peng, T.; Ma, L.; Feng, X.; Tao, J.; Nan, M.; Liu, Y.; Li, J.; Shen, L.; Wu, X.; Yu, R. Genomic and transcriptomic analyses reveal adaptation mechanisms of an Acidithiobacillus ferrivorans strain YL15 to alpine acid mine drainage. Plos ONE 2017, 12, e0178008. [CrossRef]

22. Johnson, D.B. Selective solid media for isolating and enumerating acidophilic bacteria. J. Microbiol. Methods 1995, 23, 205-218. [CrossRef]

23. Falagám, C.; Johnson, D.B. Acidithiobacillus ferriphilus sp. nov., a facultatively anaerobic iron- and sulfur-metabolizing extreme acidophile. Int. J. Syst. Evol. Microbiol. 2016, 66, 206-211.

24. Ma, L.; Wang, X.; Liu, X.; Wang, S.; Wang, H. Intensified bioleaching of chalcopyrite by communities with enriched ferrous or sulfur oxidizers. Bioresour. Technol. 2018, 268, 415-423. [CrossRef] [PubMed]

25. Tamura, H.; Goto, K.; Yotsuyanagi, T.; Nagayama, M. Spectrophotometric determination of iron(II) with 1,10-phenanthroline in the presence of large amounts of iron(III). Talanta 1974, 21, 314-318. [CrossRef]

26. Peterson, R.E.; Bollier, M.E. Spectrophotometric determination of serum copper with biscyclohexanoneoxalyldihydrazone. Anal. Chem. 1955, 27, 1195-1197. [CrossRef]

27. Li, Y.; Kawashima, N.; Li, J.; Chandra, A.P.; Gerson, A.R. A review of the structure, and fundamental mechanisms and kinetics of the leaching of chalcopyrite. Adv. Colloid Interface Sci. 2013, 197-198, 1-32. [CrossRef]

28. Christel, S.; Fridlund, J.; Buetti-Dinh, A.; Buck, M.; Watkin, E.L.; Dopson, M. RNA transcript sequencing reveals inorganic sulfur compound oxidation pathways in the acidophile Acidithiobacillus ferrivorans. Fems Microbiol. Lett. 2016, 363, fnw057. [CrossRef]

29. Wu, X.L.; Wu, X.Y.; Shen, L.; Li, J.; Yu, R.; Liu, Y.; Qiu, G.; Zeng, W. Whole genome sequencing and comparative genomics analyses of Pandoraea sp. XY-2, a new species capable of biodegrade tetracycline. Front Microbiol. 2019, 10, 33. [CrossRef] [PubMed]

30. Zhang, R.; Wei, M.; Ji, H.; Chen, X.; Qiu, G.; Zhou, H. Application of real-time PCR to monitor population dynamics of defined mixed cultures of moderate thermophiles involved in bioleaching of chalcopyrite. Appl. Microbiol. Biotechnol. 2009, 81, 1161-1168. [CrossRef]

31. Rohwerder, T.; Gehrke, T.; Kinzler, K.; Sand, W. Bioleaching review part A: Progress in bioleaching: fundamentals and mechanisms of bacterial metalsulfide oxidation. Appl. Microbiol. Biotechnol. 2003, 63, 239-248. [CrossRef] [PubMed]

32. Klauber, C.; Parker, A.; van Bronswijk, W.; Watling, H. Sulphur speciation of leached chalcopyrite surfaces as determined by X-ray photoelectron spectroscopy. Int. J. Min. Process. 2001, 62, 65-94. [CrossRef]

33. Zhu, W.; Xia, J.; Yang, Y.; Nie, Z.; Zheng, L.; Ma, C.; Zhang, R.; Peng, A.; Tang, L.; Qiu, G. Sulfur oxidation activities of pure and mixed thermophiles and sulfur speciation in bioleaching of chalcopyrite. Bioresour. Technol. 2011, 102, 3877-3882. [CrossRef] [PubMed]

34. Kupka, D.; Rzhepishevska, O.I.; Dopson, M.; Lindstrom, E.B.; Karnachuk, O.V.; Tuovinen, O.H. Bacterial oxidation of ferrous iron at low temperatures. Biotechnol. Bioeng. 2007, 97, 1470-1478. [CrossRef]

35. Liljeqvist, M.; Valdes, J.; Holmes, D.S.; Dopson, M. Draft Genome of the psychrotolerant acidophile Acidithiobacillus ferrivorans SS3. J. Bacteriol. 2011, 193, 4304-4305. [CrossRef] [PubMed]

36. Barahona, S.; Dorador, C.; Zhang, R.; Aguilar, P.; Sand, W.; Vera, M.; Remonsellez, F. Isolation and characterization of a novel Acidithiobacillus ferrivorans strain from the Chilean Altiplano: Attachment and biofilm formation on pyrite at low temperature. Res. Microbiol. 2014, 165, 782-793. [CrossRef]

(C) 2019 by the authors. Licensee MDPI, Basel, Switzerland. This article is an open access article distributed under the terms and conditions of the Creative Commons Attribution (CC BY) license (http://creativecommons.org/licenses/by/4.0/). 